\title{
From Sex Determination to Initial Folliculogenesis in Mammalian Ovaries: Morphogenetic Waves along the Anteroposterior and Dorsoventral Axes
}

\author{
Hitomi Suzuki $^{a}$ Masami Kanai-Azuma ${ }^{a}$ b Yoshiakira Kanai $^{c}$ \\ ${ }^{a}$ Department of Experimental Animal Model for Human Disease, Graduate School of Medical and \\ Dental Sciences, and ${ }^{\mathrm{b} C e n t e r}$ for Experimental Animals, Tokyo Medical and Dental University, and \\ 'Department of Veterinary Anatomy, The University of Tokyo, Tokyo, Japan
}

\section{Key Words}

FOXL2 - Germ cell cyst · Meiosis · Ovary · Ovigerous cords . Retinoic acid · Sexual bipotentiality · SRY-dependent SOX9 inducibility $\cdot$ WNT

\begin{abstract}
Gonadal sex in most mammals is determined based on sex differentiation of the supporting cell lineages. In mouse $X Y$ gonads, SRY induces SOX9 upregulation and subsequent FGF9 expression by embryonic day 11.5 (E11.5), leading to the differentiation of Sertoli cells. XX gonads, lacking SRY action, start on the ovarian program through the actions of WNT4 and FOXL2 from around E11.5-12.0. These 2 ovarian factors, together with retinoic acid (RA) action, promote feminization partially through the repression of the masculinizing activities of SOX9, FGF9 and DMRT1. RA initiates meiosis in female germ cell cysts, in which intercellular bridges between interconnected germ cells rapidly undergo cyst breakdown by E17.5. Ovarian morphogenesis is characterized by continuous recruitment of pre-granulosa progenitor cells from the coelomic epithelia during the embryonic stage, which results in the formation of ovigerous cords and tight packing of non-interconnected oocytes (i.e. oocyte nests) at the perinatal stages. At birth, the oocyte nests break
\end{abstract}

down into single oocytes surrounded by granulosa cells, leading to the assembly of primordial follicles. This review focuses on recent advances in the molecular and cellular events of initial ovarian differentiation, meiotic initiation, germ cell nest breakdown, and primordial follicle formation based on anatomical and morphogenetic aspects.

(c) 2015 S. Karger AG, Basel

\section{Background of Early Gonadogenesis}

During early organogenesis of mammalian embryos, the genital ridges arise from a thickening of the coelomic epithelium covering the mesonephric tissue along the posterior trunk around embryonic day 9.5 (E9.5) in mice [Harikae et al., 2013a; Svingen and Koopman, 2013]. In accordance with elongation of the posterior trunk, the bipotential genital ridges as future gonads become evident as a pair of long and narrow structures along an anteroposterior (AP) axis by E10.5 (leftmost image in fig. 1A) [Harikae et al., 2013a; Wainwright et al., 2014]. One of the earliest molecular events in mouse gonadogenesis is an anterior-to-posterior wave-like activation of GATA4 [Hu et al., 2013], which is a zinc finger transcription factor that is essential for the development of gonads

\section{KARGER 125}

(c) 2015 S. Karger AG, Base

$1661-5425 / 15 / 0094-0190 \$ 39.50 / 0$ 


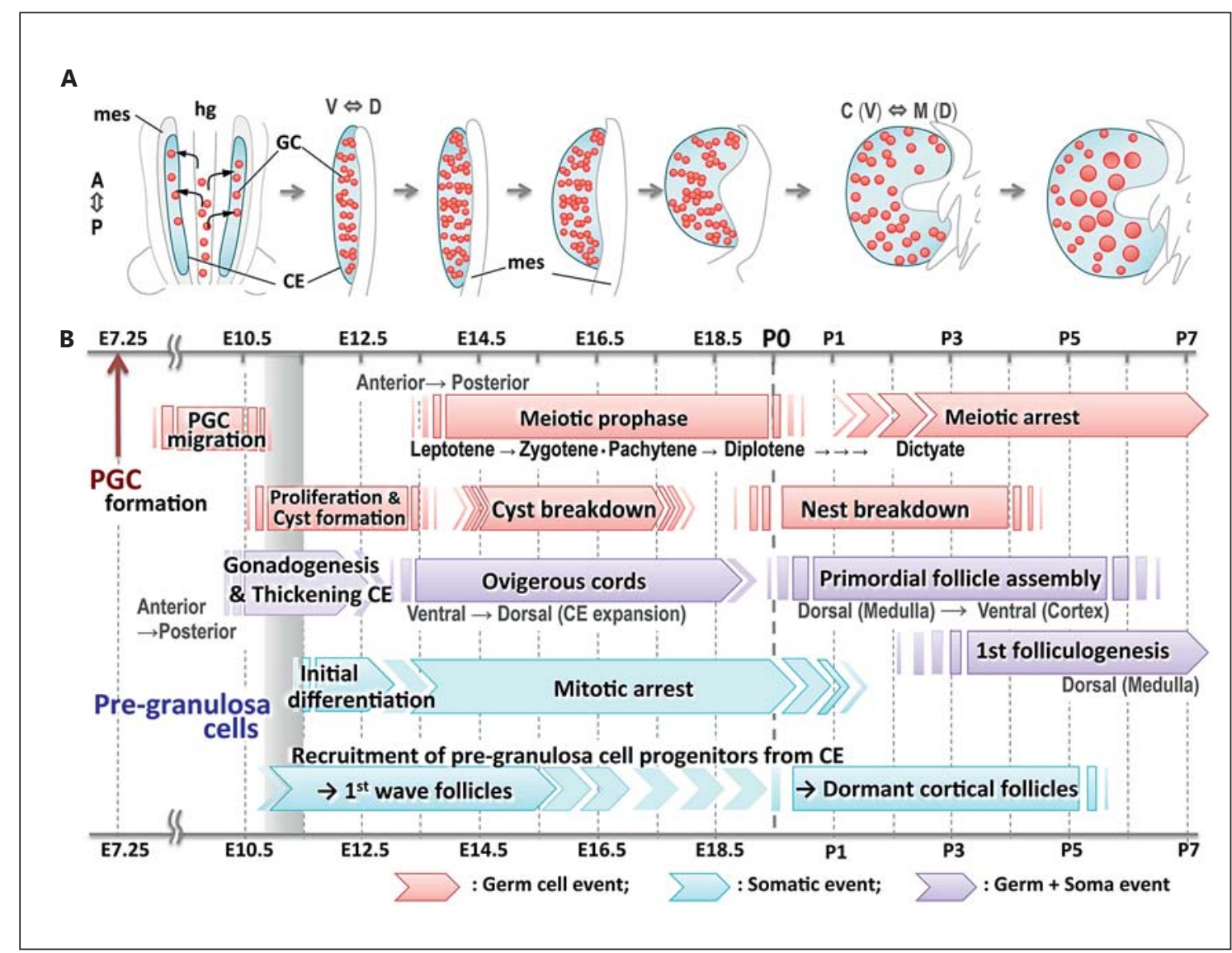

Fig. 1. Schematic representation showing spatiotemporal patterns of major cellular events during mouse ovarian differentiation and development. A Gross anatomical changes in the ovary and mesonephros (mes) along the AP and DV axes from E10.0-10.5 to postnatal day 7 (P7). Female germ cells (GC) are shown as red circles, while blue areas indicate gonadal soma. In the left-most plate, arrows represent the migration of PGCs from the hindgut (hg) to the presumptive gonadal region covered by coelomic epithelium (CE). Along the DV axis [i.e. corticomedullary (CM) axis], CE proliferation and its expansion leads to the formation of the cortical region. B The horizontal scale represents the developmental stages from

and various other tissues [review by Chlon and Crispino, 2012; Tevosian, 2014]. NR5A1/SF1, a nuclear receptor that is essential for the formation of gonads and adrenals, is also expressed in a similar anterior-to-posterior wave immediately after the onset of GATA4 expression [Schimmer and White, 2010; Hu et al., 2013]. Other potentially critical transcription factors that may help to establish genital ridge formation in mouse embryos include CBX2 [Katoh-Fukui et al., 2012], EMX2 [Kusaka et al., 2010], LHX9 [Birk et al., 2000], and WT1(-KTS) [Hammes et al., 2001; also see reviews by Schlessinger et al., 2010; Eggers et al., 2014].

From Ovarian Determination to First Folliculogenesis
E7.25 to P7. The red, blue, and purple bars represent the cellular events of GCs, somatic cells (i.e. pre-granulosa cells and CE), and morphogenetic soma-GC interactions, respectively. PGC formation at the proximal extraembryonic mesoderm at E7.25 is indicated by a red arrow, while the gray zone shows the critical time window of sex differentiation at E11.0-11.5 (i.e. the sexually bipotential state of gonadal supporting cells) [Hiramatsu et al., 2009]. In the bottom row, the arrows indicate the fate (i.e. first wave of folliculogenesis or dormant cortical follicles) of the pre-granulosa cell progenitors, which may be recruited from $\mathrm{CE}$ at each corresponding stage [Mork et al., 2012; Rastetter et al., 2014].

Because reduced expression of NR5A1/SF1 has been observed in the genital ridges of Lhx9-, Gata4- and Cbx2null embryos [Birk et al., 2000; Katoh-Fukui et al., 2012; $\mathrm{Hu}$ et al., 2013], this receptor appears to be a core transcription factor that acts downstream of these transcriptional networks during early gonadogenesis. Interestingly, a recent study suggested that NR5A1/SF1 may promote the proliferation of gonadal somatic cells partially through its direct regulation of glucose metabolism-related genes [Baba et al., 2014].

Prior to the formation of the gonadal soma starting around E10.0, the primordial germ cells (PGCs) emerge 
from the posterior extraembryonic mesoderm at around E7.25 (red arrow in fig. 1B) [Saitou et al., 2002; McLaren, 2003]. After that, PGCs move toward the genital ridges, passing through the dorsal wall of the hindgut using the morphogenetic movement of the hindgut endoderm during E8.0-9.0 [Molyneaux and Wylie, 2004; Hara et al., 2009]. At around E10.5, the PGCs migrate into the genital ridges following SCF-KIT and CXCL12/SDF1-CXCR4 signals [reviews by Molyneaux and Wylie, 2004; Richardson and Lehmann, 2010; Harikae et al., 2013a]. Importantly, however, normal gonadogenesis is not required for PGCs to enter this region in mouse embryos, as evidenced by the fact that PGCs properly migrate into the presumptive gonadal region in the genital ridges of $L h \times 9$ and Gata4-null mice without any epithelial thickening of the gonadal region [Birk et al., 2000; Hu et al., 2013]. Finally, colonization of the genital ridges by germ cells completes the establishment of the gonadal primordium consisting of germ cells and gonadal somatic cells.

Sex-specific gonadal differentiation is initiated in male gonads from around E11.0, soon after PGC settlement [review by Kanai et al., 2005; Kashimada and Koopman, 2010; Harikae et al., 2013a]. In XY gonads, the sex-determining gene on the $\mathrm{Y}(\mathrm{Sry})$ is transiently activated for $\sim 8 \mathrm{~h}$ in a center-to-pole wave-like manner along the AP axis of the gonadal region [Albrecht and Eicher, 2001; Bullejos and Koopman, 2001, 2005; Sekido et al., 2004; Kanai et al., 2005; Sekido and Lovell-Badge, 2008]. Transient SRY expression directly initiates the upregulation of SRY-related HMG box 9 (Sox9) in pre-Sertoli cells, leading to the subsequent expression of FGF9 in a similar center-to-pole wave-like pattern. FGF9 appears to be secreted from the central region toward the poles, which leads to the rapid establishment of high-level expression of SOX9 in the anterior and posterior pole domains in a positive-feedback fashion [Kim et al., 2006; Hiramatsu et al., 2010]. This SOX9-FGF9 positivefeedback system may be involved in the rapid and synchronous testiculogenesis in the long and narrow gonad along the AP axis [review by Harikae et al., 2013a].

In contrast to the simple and straight cascade of the SRY-dependent testis-determining system in early XY gonads, it remains unclear when, where and how XX female gonadal fate is determined and regulated during the fetal and perinatal stages. In this review, we focus on recent advances in the molecular and cellular events of the initial ovarian differentiation and its subsequent development in the fetal and postnatal stages. Moreover, we discuss the dynamics of ovarian differentiation along the AP and dorsoventral (DV) axes and its biological significance as related to anatomical and morphogenetic features.

\section{Initial Molecular and Cellular Events in Ovarian Differentiation}

$W N T / \beta$-Catenin Signaling in Sex-Dimorphic

Proliferation in the Coelomic Epithelial/Subepithelial

Region

After E10.5, the coelomic epithelium covering the bipotential gonad continuously undergoes proliferation, ingression, and/or expansion into the gonadal parenchy$\mathrm{ma}$ at the ventral side of the mesonephric region [Karl and Capel, 1998; Capel, 2000]. Two key factors secreted by the ovary, wingless-type MMTV integration site family member 4 (WNT4) and R-spondin homolog RSPO1, a ligand of the LGR5 receptor that regulates the WNT/ CTNNB1 ( $\beta$-catenin) signaling pathway [Carmon et al., 2011; de Lau et al., 2011], synergistically regulate the thickening of the coelomic epithelium and its subsequent expansion toward the subepithelial region in both XY and XX gonads [Chassot et al., 2012]. RSPO1/WNT4/ CTNNB1 signals have been shown to antagonize the masculinizing factors SOX9 and FGF9 downstream of Sry [Kim et al., 2006; Hiramatsu et al., 2009; Jameson et al., 2012; Nicol and Yao, 2015]. In addition to a partial sex reversal in either Wnt4 or Rspo1 mutant gonads [Vainio et al., 1999; Jeays-Ward et al., 2003; Jordan et al., 2003; Chassot et al., 2008; Tomizuka et al., 2008], ectopic expression of a stabilized form of CTNNB1 is sufficient to induce male-to-female sex reversal in XY gonads [Maatouk et al., 2008]. These data are suggestive of multiple important roles of RSPO1/WNT4/CTNNB1 signals from early gonadogenesis to ovarian differentiation.

At the early stages of E10.5 12.5, coelomic epithelial cells proliferate, ingress and expand toward the subepithelial region in both XY and XX gonads, however more evidently in XY gonads [Karl and Capel, 1998; Capel, $2000]$. At later stages ( E12.5), the expansion of proliferative epithelial cells continuously occurs only in XX gonads. This is because, after E12.5, somatic cells in the XY gonads are separated from the coelomic epithelium by the testis-specific formation of the tunica albuginea with vasculatures [Karl and Capel, 1998; Mork et al., 2012]. Also considering the high-level activation of canonical WNT/ CTNNB1 signaling in the E11.5-12.5 coelomic epithelia in both XY and XX gonads [Chassot et al., 2011, 2012], these data suggest that RSPO1/WNT4/CTNNB1 signals play crucial roles in the expansion of proliferative coelomic epithelial cells in both XY and XX gonads until E12.5. Thereafter, the signals continuously appear to induce expansion of the cortical region only in XX gonads in a sexually dimorphic manner. This in turn indicates that ova- 
ry-specific RSPO1/WNT4 signals may regulate the continuous proliferation/expansion of the cortical region in fetal and perinatal ovaries, leading to the continuous recruitment of pre-granulosa cells from the coelomic epithelium, even after birth (fig. 1B, blue bars) [Mork et al., 2012; Rastetter et al., 2014].

In addition to their crucial roles in the proliferation/ expansion of the coelomic epithelial/subepithelial regions and their antagonizing action against center-derived masculinizing FGF9 signals, the RSPO1/WNT4 signals promote not only oogonial proliferation and survival but also meiotic initiation of female germ cells in developing ovaries [Liu et al., 2010; Chassot et al., 2011]. In addition, RSPO1/WNT4/CTNNB1 signals promote female-specific expression of various key ovarian genes such as the homeobox gene Irx3 [Kim et al., 2011], the Xlinked nuclear receptor NrOb1/Dax1 [Mizusaki et al., 2003] and 2 Tgfb-related genes, Bmp2 [Yao et al., 2004; Kashimada et al., 2011], a potent suppressor of granulosa cell tumors [Pangas et al., 2008], and follistatin (Fst) [Yao et al., 2004; Kashimada et al., 2011], an antagonist for activin A, a masculinizing factor [Wu et al., 2013, 2015; Saba et al., 2014b]. The molecular and cellular actions of RSPO1/WNT4 signals, as well as the actions of forkhead box protein L2 transcription factor (FOXL2) and retinoic acid (RA), are summarized in figure 2 .

\section{Expression of FOXL2, a Core Ovarian Factor That}

Directs Granulosa Cell Fate, in a Gradient Manner

from the Mesonephric (Dorsal) Side

In developing mouse XX gonads, the initial ovary-specific molecular events occur from around E11.5, $\sim 12 \mathrm{~h}$ after the initial onset of Sry expression in the central domain of the XY gonad [Nef et al., 2005; Beverdam and Koopman, 2006; Chen et al., 2012; Munger et al., 2013], albeit with considerable variation among mouse strains, i.e. high-level expression of a large number of ovary-specific genes in the C57BL/6J strain relative to the 129S1/ SvlmJ strain at the critical time point of sex determination, E11.5 [Munger et al., 2009, 2013]. FOXL2 is one of the early ovarian factors that plays an essential role in the maintenance of ovarian phenotypes of the granulosa cells in developing ovaries [Schmidt et al., 2004; Uda et al., 2004; Ottolenghi et al., 2007; Uhlenhaut et al., 2009]. It is also a crucial female-determining gene in goats [Boulanger et al., 2014]. FOXL2 is expressed in both granulosa cells and steroidogenic theca cells, and it has multiple roles in ovarian development as a direct regulator of CYP19A1, an aromatase that synthesizes estrogens [Pannetier et al., 2006; Wang et al., 2007; Sridevi et al., 2012], and as a repressor of SOX9 and DMRT1 [Uhlenhaut et al., 2009], an evolutionarily conserved DM domain transcriptional factor that is necessary and sufficient for testis differentiation [Matson et al., 2011; Elzaiat et al., 2014; Lindeman et al., 2015; Zhao et al., 2015].

In goats, either downregulation or loss of FOXL2 transcription triggers female-to-male sex reversal [Pailhoux et al., 2001; Boulanger et al., 2014]. In mice, Foxl2-null XX gonads show no appreciable morphological evidence of sex reversal in fetuses, but do so after birth when transdifferentiation of granulosa cells into Sertoli-like cells is observed [Uda et al., 2004; Ottolenghi et al., 2005; Uhlenhaut et al., 2009]. Moreover, in adult stages, ectopic FOXL2 as well as ectopic ESR1/2 and CTNNB1 drive male-to-female transdifferentiation in Dmrt1-null Sertoli cells but not in wild-type Sertoli cells [Minkina et al., 2014]. In mouse XX gonads, FOXL2 expression is first detectable in several gonadal somatic cells located at the anterior mesonephric (anterior-dorsal) side at around E12.0, after which its expression domain rapidly expands toward the coelomic epithelial (ventral) side in addition to the anterior and posterior poles by E12.5 [see fig. S3 in Harikae et al., 2013b]. After E12.5, most of the FOXL2positive cells reside along the mesonephros, whereas only few are within the coelomic domain [Mork et al., 2012], similar to other genes that display a gradient pattern of ovary-specific expression (e.g. Slitrk1, oncRNA3 and Egfl6) in E13.5 ovaries [Chen et al., 2012].

\section{$R A$ Signaling Triggers Meiotic Initiation of Female Germ Cells in an Anterior-to-Posterior Wave-Like Pattern}

RA is a crucial regulator of not only the meiotic initiation of female germ cells [Bowles et al., 2006, 2010; Koubova et al., 2006] but also the feminizing effects on supporting cells in developing fetal gonads albeit at postnatal stages [Minkina et al., 2014]. Enhanced RA signaling accelerates transdifferentiation in Dmrt1-mutant testes, in which ectopic RA signaling alone can activate genes of female differentiation/maintenance networks via the action of RA receptor alpha (RARA) in postnatal Sertoli cells lacking DMRT1 [Minkina et al., 2014]. Therefore, it is possible that, even during fetal stages, the feminizing signals of RA, as well as WNT/CTNNB1, FOXL2 and estrogen, maintain ovarian differentiation and development, partially by antagonizing the action of DMRT1 [Minkina et al., 2014].

Aldehyde dehydrogenase family member a2/retinaldehyde dehydrogenase 2 (Aldh1a2/Raldh2), which encodes an enzyme that synthesizes RA, is highly expressed in the 
Fig. 2. Potential interactions and cascades of the major sex-specific transcriptional/ signaling factors and cellular events in ovarian differentiation. Germ cells (red frame) and pre-granulosa cells (dark blue frame) in ovarian parenchyma (light blue frame). Black and gray indicate female- and male-specific events/factors/cascades, respectively. $\mathrm{CE}=$ Coelomic epithelium.

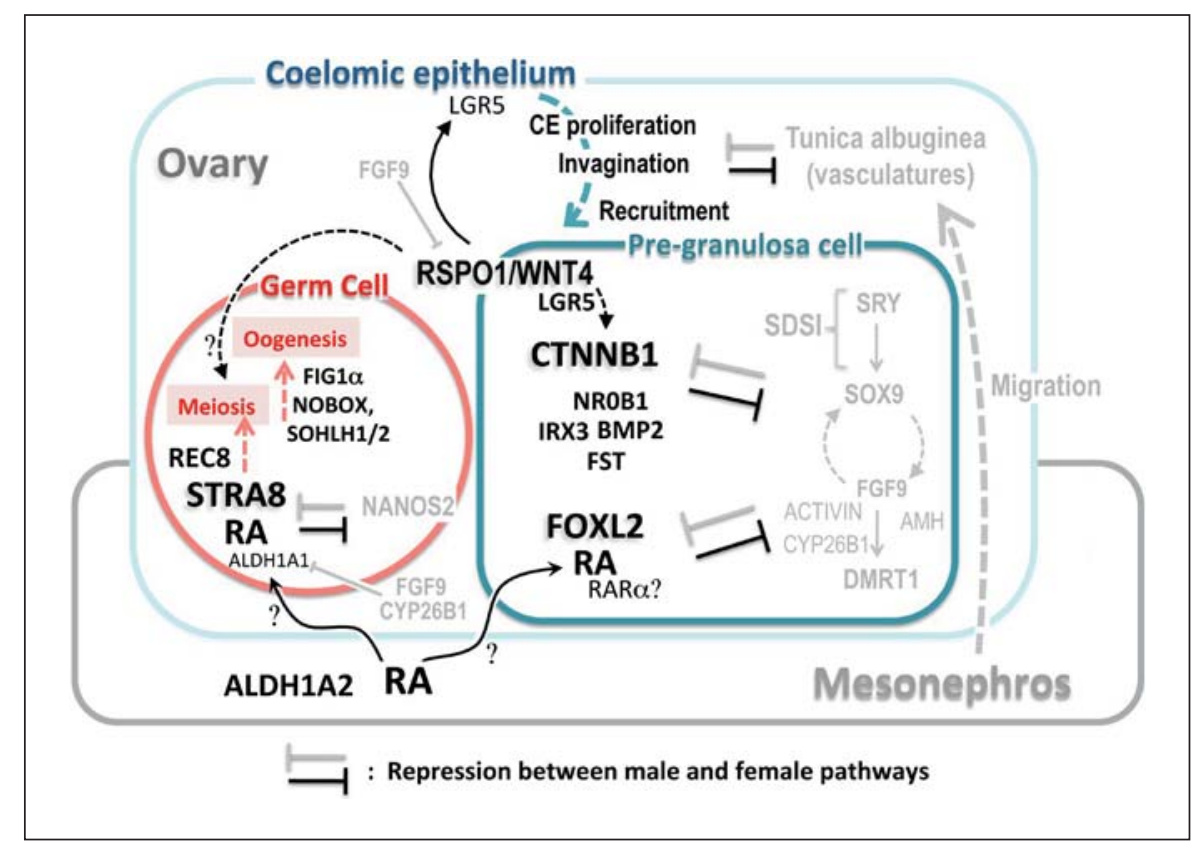

mesonephric tissues of both XY and XX gonads [Niederreither et al., 2002; Feng et al., 2014], suggestive of a potential major source of RA in developing gonads (fig. 2). In developing gonads, fetal Sertoli cells, but not ovarian somatic cells, highly express CYP26B1, a cytochrome p450 enzyme that degrades RA [Menke and Page, 2002; Bowles et al., 2006; Koubova et al., 2006]. In XX gonads, stimulated by retinoic acid gene 8 (Stra8), a meiotic initiation gene potentially induced by RA, is expressed in an anterior-to-posterior pattern starting at E12.5 [Menke et al., 2003; Bowles et al., 2006; Koubova et al., 2006]. Rec8, a meiosis-specific gene that encodes a component of the cohesin complex, is also initiated by RA signals in a similar anterior-to-posterior manner independently of Stra8 function [Koubova et al., 2014]. These data suggest that, at least in fetal germ cells, RA signals act in an anterior-toposterior manner, and their source appears to be the anterior mesonephric tissues in the ovaries of fetal mice [Bowles et al., 2006]. However, Aldh1a2/1a3-null ovaries show proper meiotic induction of female germ cells [Kumar et al., 2011]. Moreover, ALDH1A1 is expressed in germ cells of female mice from E12.5 to E15.5 [Mu et al., 2013], and the expression of the Aldh1a2 ortholog has been reported in human gonads [Childs et al., 2011] and other vertebrate species [Smith et al., 2008; Piprek et al., 2013]. Therefore, it remains unclear whether the anteriorposterior pattern of meiotic initiation is regulated by diffusible RA signals [Griswold et al., 2012] or by intrinsic factors such as the RA receptors [Gely-Pernot et al., 2012; Minkina et al., 2014; Ikami et al., 2015] and epigenetic regulators upstream of Stra 8 , such as polycomb repressive complex 1 (PRC1) [Yokobayashi et al., 2013].

\section{Loss of SRY-Dependent SOX9 Inducibility in Initial Pre-Granulosa Cell Differentiation in an Anterior-to-Posterior Wave-Like Fashion}

The earliest cellular event in developing ovaries is the loss of SRY-dependent SOX9-inducibility (SDSI) in XX gonadal supporting cells in an anterior-to-posterior wave-like manner from E11.5 to E12.0 [Hiramatsu et al., 2009; Harikae et al., 2013b]. We have previously shown that forced ubiquitous SRY activation throughout the entire region of developing XX gonads at early stages $(\sim \mathrm{E} 10.0)$ led to the formation of an XX testis with a normal spatiotemporal SOX9 expression profile, in which the gonadal supporting cells did not show any advance in timing or ectopic activation of Sox9 initiation [Kanai et al., 2005; Kidokoro et al., 2005]. These data demonstrate a tight regulation of SDSI in gonadal supporting cell precursors and provide a novel approach to estimate sexually bipotential states by monitoring the loss or reacquisition of the potency to initiate SRY-dependent Sox9 activation in developing ovaries under normal and pathological conditions. Using this novel estimation method with an Sry-inducible transgenic line, spatiotemporal changes in SDSI of ovarian somatic cells were ex- 
amined throughout the embryonic and peri- and postnatal stages [Harikae et al., 2013b]. XX pre-granulosa cell precursors maintained the SDSI until E11.5, after which most pre-granulosa cells rapidly lost this ability in an anterior-to-posterior manner by E12.0. At E12.0-12.5, most of the ovarian supporting cells, except for a small population of pre-granulosa cells located at the mesonephric side, completely lost SDSI, indicating that the loss of SDSI is one of the earliest key events in pre-granulosa cell differentiation in developing ovaries starting at around E11.5. Because the anterior-to-posterior loss of SDSI in pre-granulosa cell precursors occurs before the femalespecific expression of FOXL2 and independently of WNT4 and RA signals, some intrinsic regulators (e.g. positive/negative regulator of SRY action) may be regulated in XX supporting cells in an anterior-to-posterior fashion during E11.5 to E12.0. One candidate negative regulator of SRY action (anti-SRY factor) is the X-linked NR0B1/DAX1 [Swain et al., 1998], which represses the activation of SOX9, possibly by inhibiting the cooperative actions of SRY and NR5A1/SF1 [Ludbrook et al., 2012]. However, NrOb1/Dax1-null ovaries differentiate contrary to our expectations, with all stages of follicles present except for corpora lutea [Meeks et al., 2003], while genetic males show defective Sox9 expression [Bouma et al., 2005]. Because Nr0b1/Dax1 expression is detectable highly and widely in somatic cells of both XY and XX gonads at E11.5-12.5 [Ikeda et al., 2001], the molecular mechanisms of SDSI regulation in gonadal supporting cell precursors require further study.

In summary, in the early phase of ovarian differentiation, the anterior-to-posterior loss of SDSI first occurs in an intrinsic manner from E11.5, similar to the anteriorto-posterior expression patterns of GATA4 and NR5A1/ SF1 during the initial gonadogenesis (from $\sim$ E10.5). Next, the molecular events of ovarian differentiation in mice appear to be regulated by WNT4 and RA signaling molecules, as well as the FOXL2 transcription factor. FOXL2 expression occurs from the dorsal (mesonephric) side toward the ventral (coelomic epithelial) side from E12.0 in developing mouse ovaries. RA signals appear to be derived mainly from the anterior mesonephric tissues, which results in an anterior-to-posterior pattern of meiotic entry in female germ cells starting at E13.5. WNT4/ $\beta$ catenin signals are active in the coelomic epithelial side in both XY and XX gonads at E11.5; in later stages, and only in XX gonads, they expand throughout the whole ovarian parenchyma. The feminizing signals of WNT4, RA and FOXL2 appear to antagonize the intrinsic DMRT1 action in differentiating XX gonads by E13.5 [fig. S10 in Harikae

From Ovarian Determination to First Folliculogenesis et al., 2013b], but are competed against and repressed by a center-to-pole masculinizing wave of SRY-dependent SOX9-FGF9 positive-feedback signals in developing XY gonads. The dynamic waves of ovarian differentiation are shown schematically in figure 3.

\section{Continuous Coelomic Epithelial Proliferation Contributes to the Formation of Ovarian Ovigerous Cords along the DV Axis}

In developing XY gonads, the testis-specific formation of tunica albuginea and vasculature separate a coelomic epithelium layer from the testicular parenchyma [Capel, 2000], which results in the cessation of coelomic epithelial ingression toward the parenchyma after E12.5. On the other hand, the coelomic epithelium in XX ovaries continuously undergoes proliferation, invagination and expansion [Mork et al., 2012], leading to the formation of ovigerous cords consisting of female germ cell cysts and their surrounding flattened pre-granulosa cells (also called 'secondary cords' or 'ovarian cords') by perinatal stages. The female germ cells within the ovigerous cord appear to be extended along the DV axis by the perinatal stages. The surrounding supporting cells of these cords are continuously connected with the surface of the coelomic epithelium, but the border between the intra- and extracordal regions shows species-specific variation; for example, well-defined cords form in pigs, sheep and cows, whereas obscure cords form in mice and rats [Byskov, 1986; Sawyer et al., 2002; Mazaud et al., 2005; Hummitzsch et al., 2013, 2015].

Recently, it has become evident that, during fetal to adult stages, coelomic epithelium at the ovarian surface contains epithelial stem cells marked by the expression of LGR5, a specific marker for tissue stem cells in the intestine, skin and hair follicles [Szotek et al., 2008; FleskenNikitin et al., 2013; Ng et al., 2014]. LGR5 is a well-known $\mathrm{G}$ protein-coupled receptor for R-spondins (RSPO1-4) that are able to enhance $\mathrm{WNT} / \beta$-catenin signaling pathways in various morphogenetic processes [review by Schuijers and Clevers, 2012]. Interestingly, after E12.5, LGR5 is highly expressed in XX ovaries and this expression depends on RSPO1/WNT4 signaling [Rastetter et al., 2014]. LGR5-positive cells are restricted to the cortical region of the ovaries throughout the fetal and perinatal stages, and are fated to differentiate into granulosa cells of several growing follicles even in the first folliculogenesis [Rastetter et al., 2014; review by Hummitzsch et al., 2015]. As described above, the proliferation and expansion of 


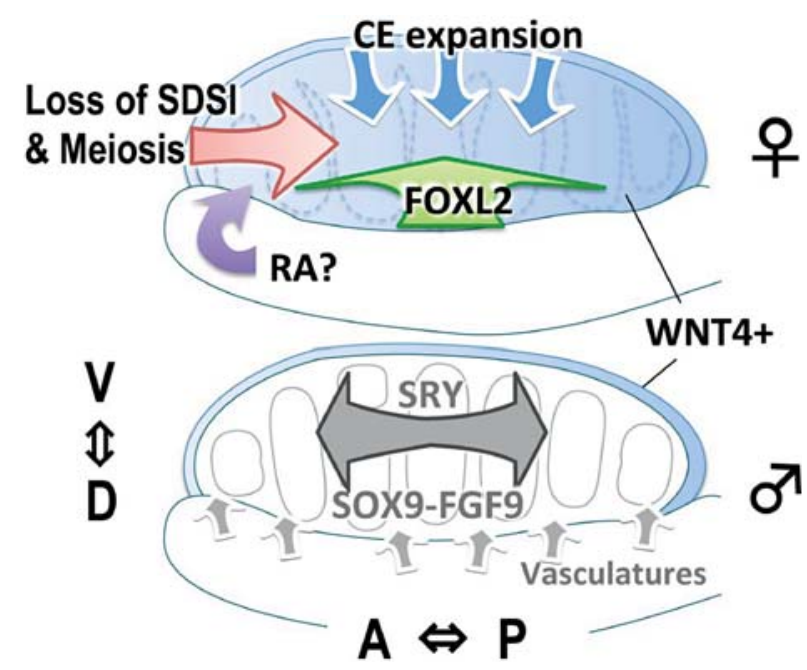

Fig. 3. Schematic representation showing dynamic waves along the AP and DV axes in gonadal somatic and germ cell differentiation during the early phases of sex differentiation. In developing ovaries, the anterior-to-posterior loss of SDSI first occurs in an intrinsic manner from E11.5 12.0 (red arrow). Meiotic entry of female germ cells is also observed with similar anterior-to-posterior patterns, which may be partially caused by the potential diffusion of RA signals from the anterior mesonephros (purple arrow). FOXL2 expression occurs in a dorsal-to-ventral manner at E12.0-12.5 (green arrow), possibly due to the temporal order of the pre-granulosa cell recruitment from coelomic epithelium at E11.0-12.0. In the coelomic epithelium, continuous proliferation and subepithelial expansion leads to the formation of the cortical parts of ovigerous cords, which may be regulated by female-specific WNT4 signals (blue arrows/area). In developing XY gonads, spontaneous activation of such feminizing factors is repressed by a center-topole masculinizing wave of a SOX9-FGF9 positive-feedback system downstream of SRY action (gray arrow) at the critical time window (E11.0-11.2) [Hiramatsu et al., 2009]. Testis-specific vasculogenesis from the mesonephros is also shown [Combes et al., 2009; Cool et al., 2011, 2012].

coelomic epithelium is induced by RSPO1/WNT4/ CTNNB1 signals in the initial stages of gonadogenesis [Chassot et al., 2012]. This appears to occur continuously in the later stages (i.e. during E12.5-14.5 and until P3 or P4) [Mork et al., 2012]. Therefore, LGR5-positive cells in the cortical region might represent the proliferating cells that lead to the ovary-specific expansion of the coelomic epithelial/subepithelial cortical region throughout the fetal and perinatal stages (fig. 2; also see the blue cells in fig. 4).

Rastetter et al. [2014] demonstrated that LGR5 single-, LGR5/FOXL2 double-, and FOXL2 single-positive pre- granulosa cells are roughly arranged in spatial order from a ventral (coelomic epithelial)-to-dorsal (mesonephric) side, and they further suggested that the LGR5-positive/ FOXL2-negative pre-granulosa cells appear to subsequently differentiate into FOXL2 single-positive pre-granulosa cells through a transient LGR5/FOXL2 double-positive state in developing ovaries. Such a cell-by-cell progressive order of pre-granulosa cell differentiation along the DV axis may reflect the spatial order of pre-granulosa cell recruitment within the ovigerous cords along the DV axis of the developing ovary (fig. 4). In addition, the DV axis-dependent arrangements of such pre-granulosa cell populations are similar to those of 3 pre-Sertoli cell populations in early XY gonads at E11.2-11.5: SRY single-, SRY/SOX9 double-, and SOX9 single-positive pre-Sertoli cells, which are roughly arrayed in spatial order from the ventral (coelomic epithelial)-to-dorsal (mesonephric) side [fig. S2 in Sekido et al., 2004; fig. 6A in Kidokoro et al., 2005; also see review by Harikae et al., 2013a].

\section{Regulation of Meiotic Initiation of Germ Cell Cysts in an Anterior-to-Posterior Manner}

After colonization of the PGCs around E10.5, fetal germ cells express DAZL, an RNA-binding protein that is essential for germ cell differentiation from the PGC state to the competent state to respond to somatic cues for gametogenesis in both sexes [Gill et al., 2011]. Simultaneously, they undergo active proliferation (doubling time of about 15-16 h) [Tam and Snow, 1981; Lei and Spradling, 2013] for genome-wide DNA demethylation reprogramming [Seisenberger et al., 2012; Kagiwada et al., 2013], leading to the formation of a germ cell cyst of $\sim 30$ germ cell clones per 1 PGC from E10.5 to E14.5 [Lei and Spradling, 2013]. From E12.5, Stra8 (a gatekeeper gene of meiosis required for pre-meiotic DNA replication) and Rec8 (a meiosis-specific gene that encodes a component of the cohesin complex) are synchronously activated within the germ cell cyst by RA signals [Bowles et al., 2006; Koubova et al., 2006, 2014], indicative of meiotic entry of female germ cells in an anterior-to-posterior pattern at E13.5-14.5. This is consistent with an opposed posterior-to-anterior pattern of the loss of PGC markers such as Pou5f1, Dppa3/PGC7/Stella and Nanos3 in developing ovaries at similar stages [Sato et al., 2002; Menke et al., 2003; Bullejos and Koopman, 2004; Ohinata et al., 2008; Yamaji et al., 2010].

In developing XY gonads, CYP26B1 (an enzyme that degrades RA) and FGF9 (a meiosis-inhibiting factor for 


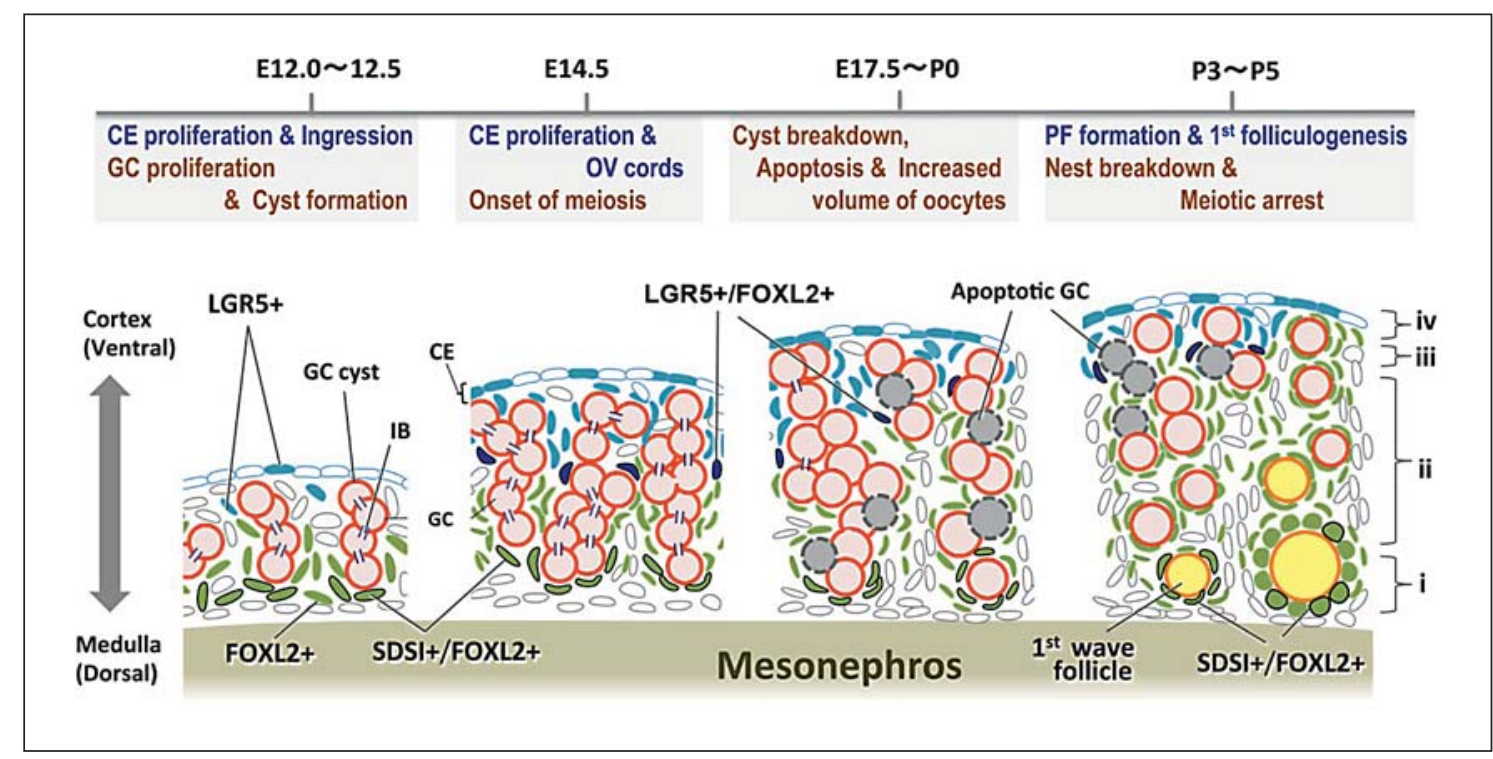

Fig. 4. Formation and reorganization of the ovigerous (OV) cords with germ cell (GC) cysts along the DV axis, leading to the first wave of folliculogenesis in the ovarian medullary region. A subpopulation of FOXL2-positive pre-granulosa cells near the mesonephric tissue continuously retains SDSI throughout the fetal and early postnatal stages (green cells with solid outline in zone i), albeit with a rapid loss of SDSI in most pre-granulosa cell precursors by E12.0. After birth, these SDSI/FOXL2 double-positive pregranulosa cells contribute to the initial round of folliculogenesis. LGR5-positive pre-granulosa cells are restricted to the cortical region throughout the fetal and perinatal stages (blue cells in zone iv). LGR5 single-, LGR5/FOXL2 double- (dark blue cells in zone iii), FOXL2 single- (green cells in zone ii), and SDSI/FOXL2 dou- ble-positive cells (green cells with solid line in zone i) are roughly arranged in spatial order from the ventral-to-dorsal side. Female GCs synchronously proliferate and form GC cysts [interconnected GCs; red circles connected by an intercellular bridge (IB)] by E14.5. These GC cysts are tightly packed with pre-granulosa cells within the OV cords extended to the DV axis. By E17.5, the majority of interconnected GCs are broken down into the 1 or 2 connected state (i.e. disruption of IB between interconnected GCs). Sequential processes of primordial follicle (PF) formation (i.e. GC apoptosis, nest breakdown, and the assembly of PFs) occur first in the medullary region and expand to the cortical region in later stages. $\mathrm{CE}=$ Coelomic epithelium. both pluripotency and masculinization of germ cells) repress Stra8 expression, thereby antagonizing the actions of RA signaling [Bowles et al., 2006, 2010; Koubova et al., 2006] (also see 'germ cell' in fig. 2). RSPO1/WNT4 and non-canonical WNT5A signals have been shown to coordinate meiotic initiation of female germ cells in developing ovaries [Vainio et al., 1999; Naillat et al., 2010; Chassot et al., 2011]. In addition, MSX1/2 [Le Bouffant et al., 2011] and DMRT1 [Krentz et al., 2011], as well as DAZL (a germ cell-intrinsic signal response factor) [Koubova et al., 2014] have been shown to be required for proper meiotic entry in female germ cells. NANOS2, an RNA-binding protein, functions as a master regulatory factor for masculinization of XY germ cells, which also represses meiotic initiation through the repression of Stra8 expression [Suzuki and Saga, 2008; Saba et al., 2014a].

Lei and Spradling [2013] demonstrated that, in mouse XX gonads, germ cells synchronously proliferate within the same clone (cyst), leading to $30 \pm 14$ cells in $4.8 \pm 3.5$ cysts at E14.5 (average 5-6 interconnected germ cells via intercellular bridges per cyst). During this period, cyst formation occurs homogenously in the whole ovarian parenchyma. However, female germ cells of each cyst appear to widely expand along the DV axis of the ovigerous cords by E14.5 (fig. 4) [fig. S4 in Lei and Spradling, 2013]. Such synchronized progression in the germ cell cyst extending along the DV axis would explain the anterior-toposterior expression profiles of Stra 8 and Rec8 in developing ovaries along the AP axis [Menke et al., 2003; Koubova et al., 2014], even if the meiosis-inducing signals of RA are diffused from anterior mesonephric tissue, one of the major sources of RA synthesis [Bowles et al., 2006]. This is because the intrinsic RA signals in each germ cell at the anterior mesonephric side might be efficiently passed into the other interconnected germ cells positioned at the coelomic epithelial side via the intercellular bridges (see 'IB' in fig. 4). Finally, most female germ cells arrest meiosis in the dictyate stage after birth through the 
leptotene-to-diplotene stages [Di Carlo et al., 2000; Ghafari et al., 2007]. Such dictyate arrest of oocytes was recently shown to be crucial for the subsequent formation of primordial follicles, as visualized by a novel technique of in situ oocyte chromosome analysis [Wang et al., 2015].

\section{Oocyte Nest Breakdown and the Assembly of Primordial Follicles, Leading to the First Wave of Folliculogenesis from the Medullary Region of the Ovary}

Cyst breakdown of the interconnected germ cells, i.e. disruption of intercellular bridges in a germ cell cyst, in developing XX gonads is one of the first cellular events for the assembly of primordial follicles [Pepling and Spradling, 2001]. The interconnected germ cells increase in number to reach a peak at E14.5 around the time of meiotic entry. The germ cell cysts are then gradually broken down into single or double connected germ cells by E17.5, a considerable time before breakdown of the oocyte nest, i.e. an aggregate of non-interconnected oocytes packed within the ovigerous cords, at $\mathrm{P} 0 \sim \mathrm{P} 2$ and the subsequent assembly of primordial follicles at $\sim \mathrm{P} 5$ (see red and purple bars in fig. 1; fig. 4) [Pepling and Spradling, 1998, 2001; Lei and Spradling, 2013]. During this process, the onset of cyst breakdown has a tendency to first occur in the mesonephric region, followed by those in the cortical region at E14.5 and E17.5 [see fig. S2D in Lei and Spradling, 2013], but there is no significant regional difference in size or cyst number of germ cell clones.

It is generally accepted that the loss of about two thirds of the oocytes accompanies oocyte nest breakdown, as low-quality oocytes are eliminated; this results in the assembly of primordial follicles at the time of birth [Pepling and Spradling, 2001]. Such oocyte loss is induced by developmentally programmed apoptotic pathways [Perez et al., 1999; Alton and Taketo, 2007; Greenfeld et al., 2007], which may be triggered by environmental changes immediately after birth, such as plummeting levels of estrogen [Jefferson et al., 2002; Chen et al., 2007, 2009]. Interestingly, this programmed nest breakdown starts in the medullary region prior to the time of birth, after which the process appears to expand toward the cortical surface region of the ovaries in humans [De Felici et al., 2005; Pepling et al., 2010]. There are similar regional differences in rat ovaries [Mazaud et al., 2005]. In contrast to the onset of germ cell cyst/nest breakdown from the medullary (dorsal)-to-cortical (ventral) side, no appreciable regional differences have been reported in the expression profiles and the loss-of-function phenotypes of several key oocyte transcription factors such as factor in the germline alpha (FIGLA) [Soyal et al., 2000], newborn ovary homeobox protein (NOBOX) [Rajkovic et al., 2004], spermatogenesis- and oogenesis-specific bHLH transcription factor 1/2 (SOHLH1/2) [Pangas et al., 2006; Choi et al., 2008b], LIM homeobox protein 8 (LHX8) [Choi et al., 2008a], and TATA box binding protein (TBP)-associated factor 4B (TAF4B) [Grive et al., 2014]. Because most oocytes in these loss-of-function mutants ultimately undergo cell death throughout the whole ovarian parenchyma shortly after birth, this homogenous loss-of-oocyte phenotype likely reflects prenatal effects of deficiencies in these transcriptional regulators to produce defective oocytes [review by Jagarlamudi and Rajkovic, 2012]. Further quantitative analyses of the spatiotemporal pattern of the onset of oocyte death and the accurate staging of defective follicular stages in each mutant may be required to understand the roles of each factor in oocyte quality control and/or its interaction with pre-granulosa cells in nest breakdown and subsequent formation of primordial follicles in the perinatal stages.

On the other hand, defective nest breakdown can lead to aberrant follicle assembly resulting in phenomena such as multi-oocyte follicles (MOFs) in postnatal ovaries. MOF phenotypes are also detectable in mutant ovaries and may include several key genes associated with pregranulosa cell differentiation such as Wnt4 [PrunskaiteHyyrylainen et al., 2014], Foxl2 [Uda et al., 2004] and Esr1/2 (estrogen receptor- $\alpha / \beta$ ) [Jefferson et al., 2002]. Such MOF phenotypes may be partially caused by masculinization in affected granulosa cells at the transcriptional level [Garcia-Ortiz et al., 2009]. In addition, the MOF phenotype is observed in various mutants, such as Notch2-Jagged1 signaling factors [Xu and Gridley, 2013; Vanorny et al., 2014], cycline-dependent kinase inhibitor 1 (Cdknb1/p27Kip1) [Perez-Sanz et al., 2013] and water channel aquaporin 8 [Su et al., 2010] [also see review by Pepling, 2012].

Similar to some DV axis-dependent regional differences in cyst/nest breakdown, the primordial follicle assemblies are initially formed preferentially in the medullary region, which engages in the first wave of folliculogenesis at P3-5 [Mork et al., 2012; Zheng et al., 2014]. The granulosa cells in dormant primordial follicles in the cortex region are newly recruited from the coelomic epithelia [Hirshfield, 1992; Hirshfield and DeSanti, 1995; Mork et al., 2012]. During this process, the ovigerous cords become fragmented as the oocytes separate, after which individual oocytes become enclosed in a layer of differenti- 
ated granulosa cells from the medullary region at the mesonephric side (dorsal side) toward the surface cortical region (ventral side) [Byskov, 1986; Pepling, 2012] (fig. 4). Lineage tracing studies using a Foxl2-CreER ${ }^{T 2}$ or Lgr5CreER ${ }^{T 2}$ mouse line have shown that most of the pregranulosa cells in ovigerous cords at E16.5 appear to contribute to primordial follicles in the initial wave of folliculogenesis after birth [Mork et al., 2012; Rastetter et al., 2014]. The first follicles in the ovarian medullary region have several characteristics that differ from the dormant primordial follicle pool in the cortical region: most are fated to undergo atresia at later stages without stimulation from pituitary-derived FSH, they show temporal differences in pre-granulosa cell recruitment from the coelomic epithelia, and their growth takes less time compared to cyclical adult follicles [Mork et al., 2012; Zheng et al., 2014].

During primordial follicle formation, pre-granulosa cells of the medullary follicles are mitotically arrested in fetal stages and then, after birth, enter a mitotically active state [Mork et al., 2012], leading to AMH-positive granulosa cells of the medullary follicles during the initial wave of folliculogenesis [Münsterberg and Lovell-Badge, 1991; Lecureuil et al., 2002; Shinomura et al., 2014]. This suggests that release from mitotic arrest in pre-granulosa cells may be crucial for follicle assembly and the subsequent initial round of folliculogenesis in the medulla. Interestingly, Wnt4- and Rspo1-null mutant ovaries have been shown to undergo precocious granulosa cell differentiation, together with the loss of germ cells, in an anterior-toposterior wave manner, which results in ectopic AMHpositive proliferative granulosa cells (albeit without any oocytes) in the anterior part of the fetal ovary [Maatouk et al., 2013]. In addition, certain somatic interactions with female germ cells at pre-meiotic stages are critical to induce precocious pre-granulosa cell differentiation in the anterior part of the Wnt4-null ovary [Maatouk et al., 2013], but such regionally distinct phenotypes may be explained, at least in part, by the anterior-to-posterior wave of female germ cell differentiation in such early stages.

Growth differentiation factor 9 (GDF9), which belongs to the TGF $\beta$ superfamily, is an oocyte-derived signaling factor that is essential for follicular development beyond the primary follicle stage [Dong et al., 1996]. GDF9 upregulates the expression of both the Desert hedgehog (Dhh) and Indian hedgehog (Ihh) genes in granulosa cells, while DHH and IHH induce the differentiation of GLI1-positive theca progenitor cells during follicle assembly and subsequent folliculogenesis of postnatal ovaries [Liu et al., 2015]. Interestingly, a subpopula-

From Ovarian Determination to First Folliculogenesis tion of steroidogenic theca progenitor cells are derived from mesonephric tissues, in which they appear to migrate toward and penetrate the ovarian medulla in perinatal stages. Therefore, it is possible that such theca progenitor cell migration from the mesonephric side partially contributes to the first folliculogenesis that occurs in the medullary region soon after birth.

Most interestingly, SDSI-positive (i.e. sexually bipotential) pre-granulosa cell location is restricted to the ovarian medullary region adjacent to the mesonephros throughout the fetal and postnatal stages [Harikae et al., 2013b] (green cells with solid outline in fig. 4). This sexually bipotential population is mitotically silent throughout the fetal life and then, soon after birth, contributes to the first wave of folliculogenesis in prepubertal stages. This is suggestive of unexpected heterogeneity in the sexual bipotentiality/plasticity of granulosa cells in the first wave of follicles in postnatal ovaries of mice. Moreover, the existence of SDSI-positive granulosa cells involved in the first wave of folliculogenesis may explain the ovotestis-like phenotype in Esr1/2- [Couse et al., 1999; Dupont et al., 2003], Foxl2/Wnt4- [Schmidt et al., 2004; Uda et al., 2004; Ottolenghi et al., 2007] and Rspo1-null ovaries [Chassot et al., 2008; Maatouk et al., 2013], in which transdifferentiation of ovarian follicles into seminiferous-like tubules with SOX9-positive Sertoli-like cells occurs in the central-medullary region during the initial wave of folliculogenesis [Dupont et al., 2003; Ottolenghi et al., 2007]. With regard to these findings, it is likely that in developing ovaries, pre-granulosa cells are heterogeneously arranged along the DV axis of the ovigerous cords in the following order: (i) SDSI/FOXL2 doublepositive, (ii) SDSI-negative/FOXL2-positive, (iii) FOXL2/ LGR5 double-positive, and (iv) FOXL2-negative/LGR5positive populations of the pre-granulosa cells from the mesonephric (dorsal) to coelomic epithelial (ventral) side (see right edge in fig. 4). Such spatial ordering allows for the recruitment of the developing follicles in a DV axisdependent manner after birth, leading to the first folliculogenesis from $\sim \mathrm{P} 2-3$.

\section{Conclusion and Future Perspectives}

In this review, we focused mainly on recent findings regarding molecular and cellular events of pre-granulosa cells from initial ovarian differentiation along the AP axis to the first folliculogenesis along the DV axis, and discussed the dynamics and biological significance of ovarian differentiation/development in terms of anatomy and 
morphogenesis. Briefly, initial gonadogenesis, marked by e.g. GATA4/NR5A1 expression, occurs in an anterior-toposterior wave-like manner, leading to dynamic waves along the AP axis in gonadal somatic and germ cell differentiation during the early phases of ovarian differentiation. Such AP-axis waves appear to be maintained at least in part by the ovigerous cords of the germ cell cysts (i.e. interconnected germ cells extended along the DV axis) by E14.5. After meiotic progression and oocyte cyst breakdown, such anterior-to-posterior waves are no longer observable and instead DV axis-dependent morphogenetic waves, which are produced by the proliferation/ expansion of the coelomic epithelial/subepithelial region at the ventral (cortical) side in addition to a cellular/signaling contribution from the dorsal (medullary) side, become apparent.

At this time, the molecular mechanisms of the initial AP-axis-dependent pre-granulosa cell differentiation (i.e. loss of SDSI) and the assembly of primordial follicles from the medullary side in the perinatal stages remain unclear, as does the significance of the initial wave of folliculogenesis from the medullary side. To resolve these questions, one approach is to identify and characterize anti-SRY factors that may cause the loss of SDSI just after the critical time window of sex determination in mice. This would clarify the function and biological significance of SDSI-positive granulosa cells located in the med- ullary region, which contributes to the initial round of folliculogenesis in postnatal ovaries. We have developed an $\mathrm{AMH}$-treck mouse line, which allows us to deplete $\mathrm{AMH}$-positive follicles in neonatal ovaries by treatment with diphtheria toxin [Shinomura et al., 2014], leading to small aberrant ovaries with a drastic reduction in the $3 \beta$-HSD-positive interstitial region during the peripubertal stages. Further detailed analyses of the phenotypes of the ovaries missing the initial round of folliculogenesis should increase our understanding of the significance of the first wave of folliculogenesis from a reproductive biological aspect. Moreover, advanced approaches such as quantitative whole-mount imaging of single cells within intact ovaries [Faire et al., 2015] and mathematical simulation of spatiotemporal changes [Da Silva-Buttkus et al., 2009] may increase our understanding of the spatiotemporal dynamics in ovigerous cords and subsequent remodeling of follicle assembly in mammals.

\section{Acknowledgements}

The authors wish to thank A/Prof. Dr. Dagmar Wilhelm and Prof. Dr. Aleksandar Rajkovic for their comments on and critical reading of the manuscript, and Ms. Yoshiko Kuroda, Yuki Uchiyama and Itsuko Yagihashi for their technical and secretarial assistance. The authors gratefully acknowledge financial supports from the Grants-in-Aid for Scientific Research (KAKENHI).

\section{References}

Albrecht KH, Eicher EM: Evidence that Sry is ex- Boulanger L, Pannetier M, Gall L, Allais-Bonnet pressed in pre-Sertoli cells and Sertoli and granulosa cells have a common precursor. Dev Biol 240:92-107 (2001).

Alton M, Taketo T: Switch from BAX-dependent to BAX-independent germ cell loss during the development of fetal mouse ovaries. J Cell Sci 120:417-424 (2007).

Baba T, Otake H, Sato T, Miyabayashi K, Shishido $\mathrm{Y}$, et al: Glycolytic genes are targets of the nuclear receptor Ad4BP/SF-1. Nat Commun 5: 3634 (2014).

Beverdam A, Koopman P: Expression profiling of purified mouse gonadal somatic cells during the critical time window of sex determination reveals novel candidate genes for human sexual dysgenesis syndromes. Hum Mol Genet 15:417-431 (2006).

Birk OS, Casiano DE, Wassif CA, Cogliati T, Zhao $\mathrm{L}$, et al: The LIM homeobox gene $\operatorname{Lh} x 9$ is essential for mouse gonad formation. Nature 403:909-913 (2000). A, Elzaiat M, et al: FOXL2 is a female sex-determining gene in the goat. Curr Biol 24:404408 (2014).

Bouma GJ, Albrecht KH, Washburn LL, Recknagel AK, Churchill GA, Eicher EM: Gonadal sex reversal in mutant Dax 1 XY mice: a failure to upregulate Sox9 in pre-Sertoli cells. Development 132:3045-3054 (2005).

Bowles J, Knight D, Smith C, Wilhelm D, Richman J, et al: Retinoid signaling determines germ cell fate in mice. Science 312:596-600 (2006).

Bowles J, Feng CW, Spiller C, Davidson TL, Jackson A, Koopman P: FGF9 suppresses meiosis and promotes male germ cell fate in mice. Dev Cell 19:440-449 (2010).

Bullejos M, Koopman P: Spatially dynamic expression of Sry in mouse genital ridges. Dev Dyn 221:201-205 (2001).

Bullejos M, Koopman P: Germ cells enter meiosis in a rostro-caudal wave during development of the mouse ovary. Mol Reprod Dev 68:422428 (2004).
Bullejos M, Koopman P: Delayed Sry and Sox 9 expression in developing mouse gonads underlies B6- $\mathrm{Y}^{\mathrm{DOM}}$ sex reversal. Dev Biol 278: 473-481 (2005).

Byskov AG: Differentiation of mammalian embryonic gonad. Physiol Rev 66:71-117 (1986).

Capel B: The battle of the sexes. Mech Dev 92: 89-103 (2000).

-Carmon KS, Gong X, Lin Q, Thomas A, Liu Q: RSpondins function as ligands of the orphan receptors LGR4 and LGR5 to regulate $\mathrm{Wnt} / \beta$ catenin signaling. Proc Natl Acad Sci USA 108:11452-11457 (2011).

Chassot AA, Ranc F, Gregoire EP, Roepers-Gajadien HL, Taketo MM, et al: Activation of $\beta$-catenin signaling by Rspol controls differentiation of the mammalian ovary. Hum Mol Genet 17:1264-1277 (2008).

Chassot AA, Gregoire EP, Lavery R, Taketo MM, de Rooij DG, et al: RSPO1/ $\beta$-catenin signaling pathway regulates oogonia differentiation and entry into meiosis in the mouse fetal ovary. PLoS One 6:e25641 (2011). 
Chassot AA, Bradford ST, Auguste A, Gregoire EP, Pailhoux E, et al: WNT4 and RSPO1 together are required for cell proliferation in the early mouse gonad. Development 139:44614472 (2012).

Chen H, Palmer JS, Thiagarajan RD, Dinger ME, Lesieur E, et al: Identification of novel markers of mouse fetal ovary development. PLoS One 7:e41683 (2012).

Chen Y, Jefferson WN, Newbold RR, PadillaBanks E, Pepling ME: Estradiol, progesterone, and genistein inhibit oocyte nest breakdown and primordial follicle assembly in the neonatal mouse ovary in vitro and in vivo. Endocrinology 148:3580-3590 (2007).

-Chen Y, Breen K, Pepling ME: Estrogen can signal through multiple pathways to regulate oocyte cyst breakdown and primordial follicle assembly in the neonatal mouse ovary. J Endocrinol 202:407-417 (2009).

Childs AJ, Cowan G, Kinnell HL, Anderson RA, Saunders PTK: Retinoic acid signalling and the control of meiotic entry in the human fetal gonad. PLoS One 6:e20249 (2011).

-Chlon TM, Crispino JD: Combinatorial regulation of tissue specification by GATA and FOG factors. Development 139:3905-3916 (2012).

Choi Y, Ballow DJ, Xin Y, Rajkovic A: Lim homeobox gene, $L h x 8$, is essential for mouse oocyte differentiation and survival. Biol Reprod 79:442-449 (2008a).

-Choi Y, Yuan D, Rajkovic A: Germ cell-specific transcriptional regulator Sohlh2 is essential for early mouse folliculogenesis and oocytespecific gene expression. Biol Reprod 79: 1176-1182 (2008b).

-Combes AN, Wilhelm D, Davidson T, Dejana E, Harley V, et al: Endothelial cell migration directs testis cord formation. Dev Biol 326:112120 (2009).

Cool J, DeFalco TJ, Capel B: Vascular-mesenchymal cross-talk through Vegf and Pdgf drives organ patterning. Proc Natl Acad Sci USA 108:167-172 (2011).

Cool J, DeFalco T, Capel B: Testis formation in the fetal mouse: dynamic and complex de novo tubulogenesis. Wiley Interdiscip Rev Dev Biol 1:847-859 (2012).

Couse JF, Hewitt SC, Bunch DO, Sar M, Walker VR, et al: Postnatal sex reversal of the ovaries in mice lacking estrogen receptors alpha and beta. Science 286:2328-2331 (1999).

Da Silva-Buttkus P, Marcelli G, Franks S, Stark J, Hardy K: Inferring biological mechanisms from spatial analysis: prediction of a local inhibitor in the ovary. Proc Natl Acad Sci USA 106:456-461 (2009).

De Felici M, Klinger FG, Farini D, Scaldaferri ML, Iona S, Lobascio M: Establishment of oocyte population in the fetal ovary: primordial germ cell proliferation and oocyte programmed cell death. Reprod Biomed Online 10:182-191 (2005).

De Lau W, Barker N, Low TY, Koo BK, Li VS, et al: Lgr5 homologues associate with Wnt receptors and mediate R-spondin signalling. Nature 476:293-297 (2011).
Di Carlo AD, Travia G, De Felici M: The meiotic specific synaptonemal complex protein SCP3 is expressed by female and male primordial germ cells of the mouse embryo. Int J Dev Biol 44:241-244 (2000).

Dong J, Albertini DF, Nishimori K, Kumar TR, Lu N, Matzuk MM: Growth differentiation factor-9 is required during early ovarian folliculogenesis. Nature 383:531-535 (1996).

Dupont S, Dennefeld C, Krust A, Chambon P, Mark M: Expression of Sox 9 in granulosa cells lacking the estrogen receptors, ER $\alpha$ and $\operatorname{ER} \beta$. Dev Dyn 226:103-106 (2003).

Eggers S, Ohnesorg T, Sinclair A: Genetic regulation of mammalian gonad development. Nat Rev Endocrinol 10:673-683 (2014).

Elzaiat M, Jouneau L, Thepot D, Klopp C, AllaisBonnet A, et al: High-throughput sequencing analyses of XX genital ridges lacking FOXL2 reveal DMRT1 up-regulation before SOX9 expression during the sex-reversal process in goats. Biol Reprod 91:153 (2014).

Faire M, Skillern A, Arora R, Nguyen DH, Wang J, et al: Follicle dynamics and global organization in the intact mouse ovary. Dev Biol 403: 69-79 (2015).

Feng CW, Bowles J, Koopman P: Control of mammalian germ cell entry into meiosis. Mol Cell Endocrinol 382:488-497 (2014).

-Flesken-Nikitin A, Hwang CI, Cheng CY, Michurina TV, Enikolopov G, Nikitin AY: Ovarian surface epithelium at the junction area contains a cancer-prone stem cell niche. Nature 495:241-245 (2013).

Garcia-Ortiz JE, Pelosi E, Omari S, Nedorezov T, Piao Y, et al: Foxl2 functions in sex determination and histogenesis throughout mouse ovary development. BMC Dev Biol 9:36 (2009).

Gely-Pernot A, Raverdeau M, Celebi C, Dennefeld C, Feret B, et al: Spermatogonia differentiation requires retinoic acid receptor $\gamma$. Endocrinology 153:438-449 (2012).

Ghafari F, Gutierrez CG, Hartshorne GM: Apoptosis in mouse fetal and neonatal oocytes during meiotic prophase one. BMC Dev Biol 7:87 (2007).

Gill ME, Hu YC, Lin Y, Page DC: Licensing of gametogenesis, dependent on RNA binding protein DAZL, as a gateway to sexual differentiation of fetal germ cells. Proc Natl Acad Sci USA 108:7443-7448 (2011).

Greenfeld CR, Pepling ME, Babus JK, Furth PA, Flaws JA: BAX regulates follicular endowment in mice. Reproduction 133:865-876 (2007).

Griswold MD, Hogarth CA, Bowles J, Koopman P: Initiating meiosis: the case for retinoic acid. Biol Reprod 86:35 (2012).

Grive KJ, Seymour KA, Mehta R, Freiman RN: TAF4b promotes mouse primordial follicle assembly and oocyte survival. Dev Biol 392: 42-51 (2014).

Hammes A, Guo JK, Lutsch G, Leheste JR, Landrock D, et al: Two splice variants of the Wilms' tumor 1 gene have distinct functions during sex determination and nephron formation. Cell 106:319-329 (2001).
Hara K, Kanai-Azuma M, Uemura M, Shitara H, Taya C, et al: Evidence for crucial role of hindgut expansion in directing proper migration of primordial germ cells in mouse early embryogenesis. Dev Biol 330:427-439 (2009).

- Harikae K, Miura K, Kanai Y: Early gonadogenesis in mammals: significance of long and narrow gonadal structure. Dev Dyn 242:330-338 (2013a).

Harikae K, Miura K, Shinomura M, Matoba S, Hiramatsu R, et al: Heterogeneity in sexual bipotentiality and plasticity of granulosa cells in developing mouse ovaries. J Cell Sci 126: 2834-2844 (2013b).

Hiramatsu R, Matoba S, Kanai-Azuma M, Tsunekawa N, Katoh-Fukui Y, et al: A critical time window of Sry action in gonadal sex determination in mice. Development 136:129138 (2009).

-Hiramatsu R, Harikae K, Tsunekawa N, Kurohmaru M, Matsuo I, Kanai Y: FGF signaling directs a center-to-pole expansion of tubulogenesis in mouse testis differentiation. Development 137:303-312 (2010).

$\rightarrow$ Hirshfield AN: Heterogeneity of cell populations that contribute to the formation of primordial follicles in rats. Biol Reprod 47:466-472 (1992)

Hirshfield AN, DeSanti AM: Patterns of ovarian cell proliferation in rats during the embryonic period and the first three weeks postpartum. Biol Reprod 53:1208-1221 (1995).

-Hu YC, Okumura LM, Page DC: Gata4 is required for formation of the genital ridge in mice. PLoS Genet 9:e1003629 (2013).

Hummitzsch K, Irving-Rodgers HF, Hatzirodos $\mathrm{N}$, Bonner W, Sabatier L, et al: A new model of development of the mammalian ovary and follicles. PLoS One 8:e55578 (2013).

Hummitzsch K, Anderson RA, Wilhelm D, Wu J, Telfer EE, et al: Stem cells, progenitor cells, and lineage decisions in the ovary. Endocr Rev 36:65-91 (2015)

Ikami K, Tokue M, Sugimoto R, Noda C, Kobayashi $\mathrm{S}$, et al: Hierarchical differentiation competence in response to retinoic acid ensures stem cell maintenance during mouse spermatogenesis. Development 142:15821592 (2015).

Ikeda Y, Takeda Y, Shikayama T, Mukai T, Hisano S, Morohashi KI: Comparative localization of Dax-1 and Ad4BP/SF-1 during development of the hypothalamic-pituitary-gonadal axis suggests their closely related and distinct functions. Dev Dyn 220:363-376 (2001).

Jagarlamudi K, Rajkovic A: Oogenesis: transcriptional regulators and mouse models. Mol Cell Endocrinol 356:31-39 (2012).

-Jameson SA, Lin YT, Capel B: Testis development requires the repression of $W n t 4$ by Fgf signaling. Dev Biol 370:24-32 (2012).

- Jeays-Ward K, Hoyle C, Brennan J, Dandonneau M, Alldus G, et al: Endothelial and steroidogenic cell migration are regulated by WNT4 in the developing mammalian gonad. Development 130:3663-3670 (2003).
From Ovarian Determination to First Folliculogenesis 
-Jefferson WN, Couse JF, Padilla-Banks E, Korach KS, Newbold RR: Neonatal exposure to genistein induces estrogen receptor (ER) a expression and multioocyte follicles in the maturing mouse ovary: evidence for ER $\beta$-mediated and nonestrogenic actions. Biol Reprod 67:12851296 (2002).

-Jordan BK, Shen JH, Olaso R, Ingraham HA, Vilain E: Wnt4 overexpression disrupts normal testicular vasculature and inhibits testosterone synthesis by repressing steroidogenic factor $1 / \beta$-catenin synergy. Proc Natl Acad Sci USA 100:10866-10871 (2003).

- Kagiwada S, Kurimoto K, Hirota T, Yamaji M, Saitou M: Replication-coupled passive DNA demethylation for the erasure of genome imprints in mice. EMBO J 32:340-353 (2013).

-Kanai Y, Hiramatsu R, Matoba S, Kidokoro T: From SRY to SOX9: mammalian testis differentiation. J Biochem 138:13-19 (2005).

Karl J, Capel B: Sertoli cells of the mouse testis originate from the coelomic epithelium. Dev Biol 203:323-333 (1998).

Kashimada K, Koopman P: Sry: the master switch in mammalian sex determination. Development 137:3921-3930 (2010).

-Kashimada K, Pelosi E, Chen H, Schlessinger D, Wilhelm D, Koopman P: FOXL2 and BMP2 act cooperatively to regulate follistatin gene expression during ovarian development. Endocrinology 152:272-280 (2011).

- Katoh-Fukui Y, Miyabayashi K, Komatsu T, Owaki A, Baba T, et al: Cbx2, a polycomb group gene, is required for Sry gene expression in mice. Endocrinology 153:913-924 (2012).

-Kidokoro T, Matoba S, Hiramatsu R, Fujisawa M, Kanai-Azuma $\mathrm{M}$, et al: Influence on spatiotemporal patterns of a male-specific Sox9 activation by ectopic Sry expression during early phases of testis differentiation in mice. Dev Biol 278:511-525 (2005).

Kim B, Kim Y, Cooke PS, Ruther U, Jorgensen JS: The fused toes locus is essential for somaticgerm cell interactions that foster germ cell maturation in developing gonads in mice. Biol Reprod 84:1024-1032 (2011).

Kim Y, Kobayashi A, Sekido R, DiNapoli L, Brennan J, et al: Fgf9 and Wnt4 act as antagonistic signals to regulate mammalian sex determination. PLoS Biol 4:e187 (2006).

Koubova J, Menke DB, Zhou Q, Capel B, Griswold MD, Page DC: Retinoic acid regulates sex-specific timing of meiotic initiation in mice. Proc Natl Acad Sci USA 103:2474-2479 (2006).

Koubova J, Hu YC, Bhattacharyya T, Soh YQ, Gill $\mathrm{ME}$, et al: Retinoic acid activates two pathways required for meiosis in mice. PLoS Genet 10:e1004541 (2014).

Krentz AD, Murphy MW, Sarver AL, Griswold MD, Bardwell VJ, Zarkower D: DMRT1 promotes oogenesis by transcriptional activation of Stra8 in the mammalian fetal ovary. Dev Biol 356:63-70 (2011).
Kumar S, Chatzi C, Brade T, Cunningham TJ, Zhao X, Duester G: Sex-specific timing of meiotic initiation is regulated by Cyp26b1 independent of retinoic acid signalling. Nat Commun 2:151 (2011).

Kusaka M, Katoh-Fukui Y, Ogawa H, Miyabayashi K, Baba T, et al: Abnormal epithelial cell polarity and ectopic epidermal growth factor receptor (EGFR) expression induced in $E m \times 2$ $\mathrm{KO}$ embryonic gonads. Endocrinology 151: 5893-5904 (2010).

Le Bouffant R, Souquet B, Duval N, Duquenne C, Herve R, et al: $M s x 1$ and $M s x 2$ promote meiosis initiation. Development 138:5393-5402 (2011).

Lecureuil C, Fontaine I, Crepieux P, Guillou F: Sertoli and granulosa cell-specific Cre recombinase activity in transgenic mice. Genesis 33: 114-118 (2002).

Lei L, Spradling AC: Mouse primordial germ cells produce cysts that partially fragment prior to meiosis. Development 140:2075-2081 (2013).

Lindeman RE, Gearhart MD, Minkina A, Krentz AD, Bardwell VJ, Zarkower D: Sexual cell-fate reprogramming in the ovary by DMRT1. Curr Biol 25:764-771 (2015).

Liu CF, Liu C, Yao HH: Building pathways for ovary organogenesis in the mouse embryo. Curr Top Dev Biol 90:263-290 (2010).

Liu C, Peng J, Matzuk MM, Yao HH: Lineage specification of ovarian theca cells requires multicellular interactions via oocyte and granulosa cells. Nat Commun 6:6934 (2015).

Ludbrook LM, Bernard P, Bagheri-Fam S, Ryan J, Sekido R, et al: Excess DAX1 leads to XY ovotesticular disorder of sex development (DSD) in mice by inhibiting steroidogenic factor-1 (SF1) activation of the testis enhancer of SRYbox-9 (Sox9). Endocrinology 153:1948-1958 (2012).

Maatouk DM, DiNapoli L, Alvers A, Parker KL, Taketo MM, Capel B: Stabilization of $\beta$-catenin in XY gonads causes male-to-female sex-reversal. Hum Mol Genet 17:29492955 (2008).

- Maatouk DM, Mork L, Chassot AA, Chaboissier MC, Capel B: Disruption of mitotic arrest precedes precocious differentiation and transdifferentiation of pregranulosa cells in the perinatal Wnt4 mutant ovary. Dev Biol 383:295306 (2013).

Matson CK, Murphy MW, Sarver AL, Griswold MD, Bardwell VJ, Zarkower D: DMRT1 prevents female reprogramming in the postnatal mammalian testis. Nature 476:101-104 (2011).

Mazaud S, Guyot R, Guigon CJ, Coudouel N, Le Magueresse-Battistoni B, Magre S: Basal membrane remodeling during follicle histogenesis in the rat ovary: contribution of proteinases of the MMP and PA families. Dev Biol 277:403-416 (2005).

McLaren A: Primordial germ cells in the mouse. Dev Biol 262:1-15 (2003).

Meeks JJ, Weiss J, Jameson JL: Dax1 is required for testis determination. Nat Genet 34:32-33 (2003).
Menke DB, Page DC: Sexually dimorphic gene expression in the developing mouse gonad. Gene Expr Patterns 2:359-367 (2002).

Menke DB, Koubova J, Page DC: Sexual differentiation of germ cells in XX mouse gonads occurs in an anterior-to-posterior wave. Dev Biol 262:303-312 (2003).

Minkina A, Matson CK, Lindeman RE, Ghyselinck NB, Bardwell VJ, Zarkower D: DMRT1 protects male gonadal cells from retinoid-dependent sexual transdifferentiation. Dev Cell 29:511-520 (2014).

Mizusaki H, Kawabe K, Mukai T, Ariyoshi E, Kasahara M, et al: Dax-1 (dosage-sensitive sex reversal-adrenal hypoplasia congenita critical region on the $\mathrm{X}$ chromosome, gene 1) gene transcription is regulated by Wnt4 in the female developing gonad. Mol Endocrinol 17: 507-519 (2003).

Molyneaux K, Wylie C: Primordial germ cell migration. Int J Dev Biol 48:537-544 (2004).

-Mork L, Maatouk DM, McMahon JA, Guo JJ, Zhang $\mathrm{P}$, et al: Temporal differences in granulosa cell specification in the ovary reflect distinct follicle fates in mice. Biol Reprod 86:37 (2012).

Mu X, Wen J, Guo M, Wang J, Li G, et al: Retinoic acid derived from the fetal ovary initiates meiosis in mouse germ cells. J Cell Physiol 228:627-639 (2013).

Munger SC, Aylor DL, Syed HA, Magwene PM, Threadgill DW, Capel B: Elucidation of the transcription network governing mammalian sex determination by exploiting strain-specific susceptibility to sex reversal. Genes Dev 23: 2521-2536 (2009).

Munger SC, Natarajan A, Looger LL, Ohler U, Capel B: Fine time course expression analysis identifies cascades of activation and repression and maps a putative regulator of mammalian sex determination. PLoS Genet 9: e1003630 (2013).

Münsterberg A, Lovell-Badge R: Expression of the mouse anti-müllerian hormone gene suggests a role in both male and female sexual differentiation. Development 113:613-624 (1991).

Naillat F, Prunskaite-Hyyrylainen R, Pietila I, Sormunen R, Jokela T, et al: Wnt4/5a signalling coordinates cell adhesion and entry into meiosis during presumptive ovarian follicle development. Hum Mol Genet 19:1539-1550 (2010).

- Nef S, Schaad O, Stallings NR, Cederroth CR, Pitetti JL, et al: Gene expression during sex determination reveals a robust female genetic program at the onset of ovarian development. Dev Biol 287:361-377 (2005).

Ng A, Tan S, Singh G, Rizk P, Swathi Y, et al: Lgr5 marks stem/progenitor cells in ovary and tubal epithelia. Nat Cell Biol 16:745-757 (2014).

Nicol B, Yao HH: Gonadal identity in the absence of pro-testis factor SOX9 and pro-ovary factor beta-catenin in mice. Biol Reprod 93:35 (2015).

Niederreither K, Fraulob V, Garnier JM, Chambon P, Dolle P: Differential expression of retinoic acid-synthesizing (RALDH) enzymes during fetal development and organ differentiation in the mouse. Mech Dev 110:165-171 (2002). 
Ohinata Y, Sano M, Shigeta M, Yamanaka K, Saitou M: A comprehensive, non-invasive visualization of primordial germ cell development in mice by the Prdm1-mVenus and Dppa3-ECFP double transgenic reporter. Reproduction 136:503-514 (2008).

-Ottolenghi C, Omari S, Garcia-Ortiz JE, Uda M, Crisponi L, et al: Foxl2 is required for commitment to ovary differentiation. Hum Mol Genet 14:2053-2062 (2005).

-Ottolenghi C, Pelosi E, Tran J, Colombino M, Douglass E, et al: Loss of Wnt4 and Foxl2 leads to female-to-male sex reversal extending to germ cells. Hum Mol Genet 16:2795-2804 (2007).

Pailhoux E, Vigier B, Chaffaux S, Servel N, Taourit $\mathrm{S}$, et al: A $11.7-\mathrm{kb}$ deletion triggers intersexuality and polledness in goats. Nat Genet 29:453-458 (2001).

-Pangas SA, Choi Y, Ballow DJ, Zhao Y, Westphal $\mathrm{H}$, et al: Oogenesis requires germ cell-specific transcriptional regulators Sohlh1 and Lhx8. Proc Natl Acad Sci USA 103:8090-8095 (2006).

-Pangas SA,LiX, Umans L, Zwijsen A, Huylebroeck D, et al: Conditional deletion of Smad1 and Smad5 in somatic cells of male and female gonads leads to metastatic tumor development in mice. Mol Cell Biol 28:248-257 (2008).

-Pannetier M, Fabre S, Batista F, Kocer A, Renault $L$, et al: FOXL2 activates $P 450$ aromatase gene transcription: towards a better characterization of the early steps of mammalian ovarian development. J Mol Endocrinol 36:399-413 (2006).

Pepling ME: Follicular assembly: mechanisms of action. Reproduction 143:139-149 (2012).

-Pepling ME, Spradling AC: Female mouse germ cells form synchronously dividing cysts. Development 125:3323-3328 (1998).

- Pepling ME, Spradling AC: Mouse ovarian germ cell cysts undergo programmed breakdown to form primordial follicles. Dev Biol 234:339351 (2001).

-Pepling ME, Sundman EA, Patterson NL, Gephardt GW, Medico L Jr, Wilson KI: Differences in oocyte development and estradiol sensitivity among mouse strains. Reproduction 139:349-357 (2010).

-Perez GI, Robles R, Knudson CM, Flaws JA, Korsmeyer SJ, Tilly JL: Prolongation of ovarian lifespan into advanced chronological age by Bax-deficiency. Nat Genet 21:200-203 (1999).

-Perez-Sanz J, Arluzea J, Matorras R, GonzalezSantiago N, Bilbao J, et al: Increased number of multi-oocyte follicles (MOFs) in juvenile p27Kip1 mutant mice: potential role of granulosa cells. Hum Reprod 28:1023-1030 (2013).

-Piprek RP, Pecio A, Laskowska-Kaszub K, Kloc M, Kubiak JZ, Szymura JM: Retinoic acid homeostasis regulates meiotic entry in developing anuran gonads and in bidder's organ through Raldh2 and Cyp26b1 proteins. Mech Dev 130:613-627 (2013).

- Prunskaite-Hyyrylainen R, Shan J, Railo A, Heinonen KM, Miinalainen I, et al: Wnt4, a pleio- tropic signal for controlling cell polarity, basement membrane integrity, and antimüllerian hormone expression during oocyte maturation in the female follicle. FASEB J 28 : 1568-1581 (2014).

Rajkovic A, Pangas SA, Ballow D, Suzumori N, Matzuk MM: NOBOX deficiency disrupts early folliculogenesis and oocyte-specific gene expression. Science 305:1157-1159 (2004).

Rastetter RH, Bernard P, Palmer JS, Chassot AA, Chen $\mathrm{H}$, et al: Marker genes identify three somatic cell types in the fetal mouse ovary. Dev Biol 394:242-252 (2014)

Richardson BE, Lehmann R: Mechanisms guiding primordial germ cell migration: strategies from different organisms. Nat Rev Mol Cell Biol 11:37-49 (2010).

-Saba R, Kato Y, Saga Y: NANOS2 promotes male germ cell development independent of meiosis suppression. Dev Biol 385:32-40 (2014a).

- Saba R, Wu Q, Saga Y: CYP26B1 promotes male germ cell differentiation by suppressing STRA8-dependent meiotic and STRA8-independent mitotic pathways. Dev Biol 389:173181 (2014b).

-Saitou M, Barton SC, Surani MA: A molecular programme for the specification of germ cell fate in mice. Nature 418:293-300 (2002).

Sato M, Kimura T, Kurokawa K, Fujita Y, Abe K, et al: Identification of $P G C 7$, a new gene expressed specifically in preimplantation embryos and germ cells. Mech Dev 113:91-94 (2002).

- Sawyer HR, Smith P, Heath DA, Juengel JL, Wakefield SJ, McNatty KP: Formation of ovarian follicles during fetal development in sheep. Biol Reprod 66:1134-1150 (2002).

-Schimmer BP, White PC: Minireview: steroidogenic factor 1: its roles in differentiation, development, and disease. Mol Endocrinol 24: 1322-1337 (2010).

-Schlessinger D, Garcia-Ortiz JE, Forabosco A, Uda M, Crisponi L, Pelosi E: Determination and stability of gonadal sex. J Androl 31:1625 (2010)

- Schmidt D, Ovitt CE, Anlag K, Fehsenfeld S, Gredsted L, et al: The murine winged-helix transcription factor Foxl2 is required for granulosa cell differentiation and ovary maintenance. Development 131:933-942 (2004).

Schuijers J, Clevers H: Adult mammalian stem cells: the role of Wnt, Lgr5 and R-spondins. EMBO J 31:2685-2696 (2012).

-Seisenberger S, Andrews S, Krueger F, Arand J, Walter J, et al: The dynamics of genome-wide DNA methylation reprogramming in mouse primordial germ cells. Mol Cell 48:849-862 (2012).

Sekido R, Lovell-Badge R: Sex determination involves synergistic action of SRY and SF1 on a specific Sox9 enhancer. Nature 453:930-934 (2008).

Sekido R, Bar I, Narvaez V, Penny G, LovellBadge R: SOX9 is up-regulated by the transient expression of SRY specifically in Sertoli cell precursors. Dev Biol 274:271-279 (2004).
Shinomura M, Kishi K, Tomita A, Kawasumi M, Kanezashi H, et al: A novel Amh-treck transgenic mouse line allows toxin-dependent loss of supporting cells in gonads. Reproduction 148:H1-H9 (2014).

-Smith CA, Roeszler KN, Bowles J, Koopman P, Sinclair AH: Onset of meiosis in the chicken embryo; evidence of a role for retinoic acid. BMC Dev Biol 8:85 (2008).

- Soyal SM, Amleh A, Dean J: FIGa, a germ cellspecific transcription factor required for ovarian follicle formation. Development 127: 4645-4654 (2000).

- Sridevi P, Chaitanya RK, Dutta-Gupta A, Senthilkumaran B: FTZ-F1 and FOXL2 up-regulate catfish brain aromatase gene transcription by specific binding to the promoter motifs. Biochim Biophys Acta 1819:57-66 (2012).

- Su W, Qiao Y, Yi F, Guan X, Zhang D, et al: Increased female fertility in aquaporin 8 -deficient mice. IUBMB Life 62:852-857 (2010).

-Suzuki A, Saga Y: Nanos2 suppresses meiosis and promotes male germ cell differentiation. Genes Dev 22:430-435 (2008).

-Svingen T, Koopman P: Building the mammalian testis: origins, differentiation, and assembly of the component cell populations. Genes Dev 27:2409-2426 (2013).

-Swain A, Narvaez V, Burgoyne P, Camerino G, Lovell-Badge R: Daxl antagonizes Sry action in mammalian sex determination. Nature 391:761-767 (1998).

-Szotek PP, Chang HL, Brennand K, Fujino A, Pieretti-Vanmarcke R, et al: Normal ovarian surface epithelial label-retaining cells exhibit stem/progenitor cell characteristics. Proc Natl Acad Sci USA 105:12469-12473 (2008).

-Tam PP, Snow MH: Proliferation and migration of primordial germ cells during compensatory growth in mouse embryos. J Embryol Exp Morphol 64:133-147 (1981).

Tevosian SG: Transgenic mouse models in the study of reproduction: insights into GATA protein function. Reproduction 148:R1-R14 (2014).

- Tomizuka K, Horikoshi K, Kitada R, Sugawara Y, Iba Y, et al: R-spondin 1 plays an essential role in ovarian development through positively regulating Wnt-4 signaling. Hum Mol Genet 17:1278-1291 (2008).

-Uda M, Ottolenghi C, Crisponi L, Garcia JE, Deiana $\mathrm{M}$, et al: Foxl2 disruption causes mouse ovarian failure by pervasive blockage of follicle development. Hum Mol Genet 13: 1171-1181 (2004).

Uhlenhaut NH, Jakob S, Anlag K, Eisenberger T, Sekido R, et al: Somatic sex reprogramming of adult ovaries to testes by FOXL2 ablation. Cell 139:1130-1142 (2009).

Vainio S, Heikkila M, Kispert A, Chin N, McMahon AP: Female development in mammals is regulated by Wnt-4 signalling. Nature 397 : 405-409 (1999).

Vanorny DA, Prasasya RD, Chalpe AJ, Kilen SM, Mayo KE: Notch signaling regulates ovarian follicle formation and coordinates follicular growth. Mol Endocrinol 28:499-511 (2014).
From Ovarian Determination to First Folliculogenesis 
Wainwright EN, Svingen T, Ng ET, Wicking C, Koopman P: Primary cilia function regulates the length of the embryonic trunk axis and urogenital field in mice. Dev Biol 395:342354 (2014).

Wang DS, Kobayashi T, Zhou LY, Paul-Prasanth B, Ijiri S, et al: Foxl2 up-regulates aromatase gene transcription in a female-specific manner by binding to the promoter as well as interacting with $\mathrm{Ad} 4$ binding protein/steroidogenic factor 1. Mol Endocrinol 21:712-725 (2007).

Wang Y, Teng Z, Li G, Mu X, Wang Z, et al: Cyclic AMP in oocytes controls meiotic prophase I and primordial folliculogenesis in the perinatal mouse ovary. Development 142:343-351 (2015).
Wu Q, Kanata K, Saba R, Deng CX, Hamada H, Saga Y: Nodal/activin signaling promotes male germ cell fate and suppresses female programming in somatic cells. Development 140:291-300 (2013).

Wu Q, Fukuda K, Weinstein M, Graff JM, Saga Y: SMAD2 and p38 signaling pathways act in concert to determine $\mathrm{XY}$ primordial germ cell fate in mice. Development 142:575-586 (2015).

Xu J, Gridley T: Notch2 is required in somatic cells for breakdown of ovarian germ-cell nests and formation of primordial follicles. BMC Biol 11:13 (2013).

Yamaji M, Tanaka T, Shigeta M, Chuma S, Saga Y, Saitou M: Functional reconstruction of NANOS3 expression in the germ cell lineage by a novel transgenic reporter reveals distinct subcellular localizations of NANOS3. Reproduction 139:381-393 (2010).
Yao HH, Matzuk MM, Jorgez CJ, Menke DB, Page DC, et al: Follistatin operates downstream of Wnt4 in mammalian ovary organogenesis. Dev Dyn 230:210-215 (2004).

- Yokobayashi S, Liang CY, Kohler H, Nestorov P, Liu Z, et al: PRC1 coordinates timing of sexual differentiation of female primordial germ cells. Nature 495:236-240 (2013).

Zhao L, Svingen T, Ng ET, Koopman P: Femaleto-male sex reversal in mice caused by transgenic overexpression of Dmrt1. Development 142:1083-1088 (2015).

Zheng W, Zhang H, Gorre N, Risal S, Shen Y, Liu K: Two classes of ovarian primordial follicles exhibit distinct developmental dynamics and physiological functions. Hum Mol Genet 23: 920-928 (2014). 